\title{
The importance of videolaryngoscopy in maxillofacial practice associated with restricted mouth opening in traumatized patients
}

\author{
A importância da videolaringoscopia na prática bucomaxilofacial associada a restrição de abertura \\ bucal de pacientes traumatizados \\ La importancia de la videolaringoscopia en la práctica maxilofacial asociada a la apertura bucal \\ restringida en pacientes traumatizados
}

Received: 01/19/2021 | Reviewed: 01/23/2021 | Accept: 01/31/2021 | Published: 02/07/2021

Leonardo Alan Delanora

ORCID: https://orcid.org/0000-0002-3002-4420 Universidade Estadual Paulista, Brazil E-mail: leonardoaland@gmail.com

Ana Maira Pereira Baggio

ORCID: https://orcid.org/0000-0002-9474-5091 Universidade Estadual Paulista, Brazil E-mail: anamairabaggio@gmail.com Nathália Januario de Araujo

ORCID: https://orcid.org/0000-0003-4859-0583 Universidade Estadual Paulista, Brazil E-mail: nathaliajanuario56@gmail.com

William Phillip Pereira da Silva

ORCID: https://orcid.org/0000-0003-4172-7217 Universidade Estadual Paulista, Brazil E-mail: william_phillip@hotmail.com

Leonardo Perez Faverani ORCID: https://orcid.org/0000-0003-2249-3048 Universidade Estadual Paulista, Brazil E-mail: leonardo.faverani@unesp.br

Ana Paula Farnezi Bassi

ORCID: https://orcid.org/0000-0002-0031-4953 Universidade Estadual Paulista, Brazil E-mail: ana.bassi@unesp.br

\begin{abstract}
Orotracheal intubation is considered the most delicate maneuver performed by anesthesiologists, and failure to manage the airways is one of the main causes of possible complications that can be catastrophic during its performance, thus requiring good team planning. Anatomical and / or physiological characteristics, such as limited mouth opening, a condition often found in patients suffering from fractures of the zygomatic arch or who have some abnormality in the temporomandibular joint (TMJ), can characterize a difficult airway, which demands attention greatest of the professional. Therefore, in order to overcome the obstacles that may occur during a difficult or unexpected intubation, new tools have been used, such as videolaryngoscopy in which an intubation device containing miniature video cameras is used in order to allow the operator has an indirect view of the glottis to increase success rates and decrease intubation time. The aim of the present study is to report a clinical case of a trauma victim, with limited mouth opening, who underwent intubation with the aid of a video laryngoscope after failed attempts at conventional intubation.
\end{abstract}

Keywords: Intubation; Trism; Laryngoscopy.

\section{Resumo}

A intubação orotraqueal é considerada a manobra mais delicada realizada pelos anestesiologistas e a falha no manejo das vias aéreas é uma das principais causas de possíveis complicações que podem ser catastróficas durante a sua realização, sendo necessário portanto, um bom planejamento da equipe. Características anatômicas e/ou fisiológicas como por exemplo a limitação da abertura bucal, condição frequentemente encontrada em pacientes vítimas de fratura do arco zigomático ou que possuem alguma anormalidade na articulação temporomandibular (ATM), podem caracterizar uma via aérea difícil, o que demanda uma atenção maior do profissional. Sendo assim, a fim de superar os obstáculos que podem ocorrer durante uma intubação difícil ou inesperada, novas ferramentas vêm sendo utilizadas, como a videolaringoscopia na qual utiliza-se um dispositivo de intubação que contém câmeras de vídeo em miniatura com o objetivo de permitir que o operador tenha uma visão indireta da glote para aumentar as taxas de sucesso e 
diminuir o tempo de intubação. O objetivo do presente trabalho é relatar um caso clínico de um paciente vítima de trauma, com limitação de abertura bucal, submetido à intubação com o auxílio de um videolaringoscópio após tentativas falhas na realização da intubação convencional.

Palavras-chave: Intubação; Trismo; Laringoscopia.

\section{Resumen}

La intubación orotraqueal se considera la maniobra más delicada que realizan los anestesiólogos, y la falta de manejo de la vía aérea es una de las principales causas de posibles complicaciones que pueden ser catastróficas durante su realización, por lo que requieren una buena planificación del equipo. Las características anatómicas y / o fisiológicas, como la apertura bucal limitada, una condición que se encuentra a menudo en pacientes que sufren fracturas del arco cigomático o que tienen alguna anomalía en la articulación temporomandibular (ATM), pueden caracterizar una vía aérea difícil, que requiere atención. el más grande del profesional. Por ello, para superar los obstáculos que pueden presentarse durante una intubación difícil o inesperada, se han utilizado nuevas herramientas, como la videolaringoscopia en la que se utiliza un dispositivo de intubación que contiene cámaras de video en miniatura para permitir el operador tiene una vista indirecta de la glotis para aumentar las tasas de éxito y disminuir el tiempo de intubación. El objetivo del presente estudio es reportar un caso clínico de una víctima de trauma, con apertura bucal limitada, que fue sometida a intubación con la ayuda de un videolaringoscopio luego de intentos fallidos de intubacíon convencional.

Palabras clave: Intubación; Trismo; Laringoscopia.

\section{Introduction}

The introduction of new tools in clinical practice for intubation is necessary in order to overcome the difficulties that may appear during an intubation of patients with difficult airways (VAD) (Ciccozzi et al., 2013, Kilicaslan et al., 2014, Cunha Andrade et al., 2018). Among the situations that require more caution from the professional and that can characterize a difficult intubation, are the removal distance $(<12.5 \mathrm{~cm})$, hyoid distance $(<6 \mathrm{~cm})$, Mallampati classification $(3$ or 4$)$, reduced mandibular protrusion, neck circumference $(>40 \mathrm{~cm})$, obstructive sleep apnea syndrome, macroglossia, mandibular or dental abnormalities, history of snoring, restricted mouth opening (interincisive distance), among others (Erdivanli et al., 2018, Cunha Andrade et al., 2018, Selvi et al., 2020, Apfelbaum et al., 2013, Detsky et al., 2019, Nausheen et al., 2019).

The patient's mouth opening must be at least $2 \mathrm{~cm}$, and this means that there is enough space to position the blade between the upper and lower teeth. The presence of trismus and problems in the temporomandibular joint can reduce this distance and, consequently, increase the difficulty of visualization and manipulation of important anatomical structures, which can prevent the success of intubation (Erdivanli et al., 2018, Detsky et al., 2019, Turcio et al., 2017, Jungbauer et al., 2009).

Patients suffering from fractures of the zygomatic arch often have limited mouth opening and flattening of the middle third of the face. The zygomatic arch is formed by the temporal process of the zygomatic bone and by the zygomatic process of the temporal bone and in it, the masseter and temporal fascia are fixed (Chang et al., 2012, Trindade et al., 2012, Pereira, et al., 2014). Trismus may result from mechanical impairment of the coronoid process of the mandible, impact on the masseter and temporal fascia, rupture of the fracture of the zygomatic-maxillary complex or even muscle spasms due to fracture of the zygomatic arch (Chang et al., 2012, Trindade et al., 2012, Pereira et al., 2014).

Given this scenario, when conventional laryngoscopes are not satisfactory, videolaryngoscopy is one of the tools that can be used to facilitate intubation in the event of a difficult airway (Ciccozzi et al., 2013, Erdivanli et al., 2018, Kilicaslan et al., 2014, Apfelbaum et al., 2013, Jungbauer et al., 2009, Aziz et al., 2012) and through it, it is possible to obtain a better view of the laryngeal structures, with faster intubations and less need for optimization maneuvers through the use of video laryngoscopes (Ciccozzi et al., 2013, Kilicaslan et al., 2014, Jungbauer et al., 2009, Berkow et al., 2018, Niforopoulou et al., 2010). However, there are still controversies in the literature (Erdivanli et al., 2018 \& Aziz et al., 2012) whether videolaryngoscopy can increase the success of intubation particularly in the predicted difficult airway, as some studies have limited interpretive value (Aziz et al., 2012 \& Berkow et al., 2018).

Video laryngoscopes usually have a light source at the tip of their blade and a camera that projects the image in real 
time to a portable video system, thus, another advantage that can be mentioned, is that they allow to abandon the need for alignment of the oral, pharyngeal and tracheal axes to receive a direct view of the glottis, which facilitates the intubation of patients with pathology or immobilization of the cervical spine (Ciccozzi et al., 2013, Erdivanli et al., 2018, Kilicaslan et al., 2014, Jungbauer et al., 2009, Aziz et al., 2012, Berkow et al., 2018, Niforopoulou et al., 2010).

\section{Methodology}

The presente work approaches a case report in a quantitative and qualitative way with the objective of reporting the performance of a videolaryngoscopy after failed attempts in the performance of conventional laryngoscopy, in a patient victim of trauma to the face, with limited mouth opening resulting from fracture in the arch zygomatic. The Free and Informed Consent Term was signed by the patient, following all protocols under the same consent term (Pereira et al., 2018, Delanora et al., 2020).

\section{Case Report}

A victim of an accident at work, 15 days ago, suffered a trauma during the installation of a marble statue in the right malar region with a sinking of the region. During the physical examination, a mouth opening restriction of less than 20 mm was found, as shown in Figure 1.

Figure 1 - Extra-oral aspect.

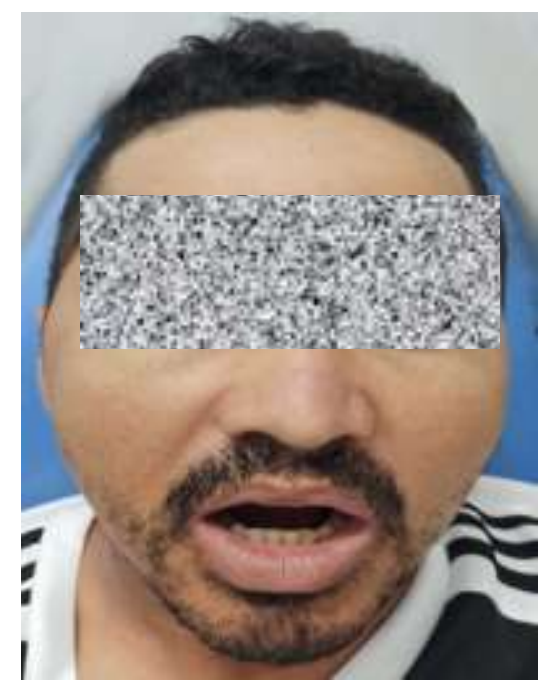

Source: Authors.

In Figure 1, it is possible to see an edema in the patient's right malar region, in the frontal view, in addition to the edema, the maximum mouth opening of the patient at the time of the physical examination, of approximately 20 millimeters, is visible.

Computed tomography imaging was performed to observe the fracture (Figure 2). 
Figure 2 - Preoperative computed tomography of the face.

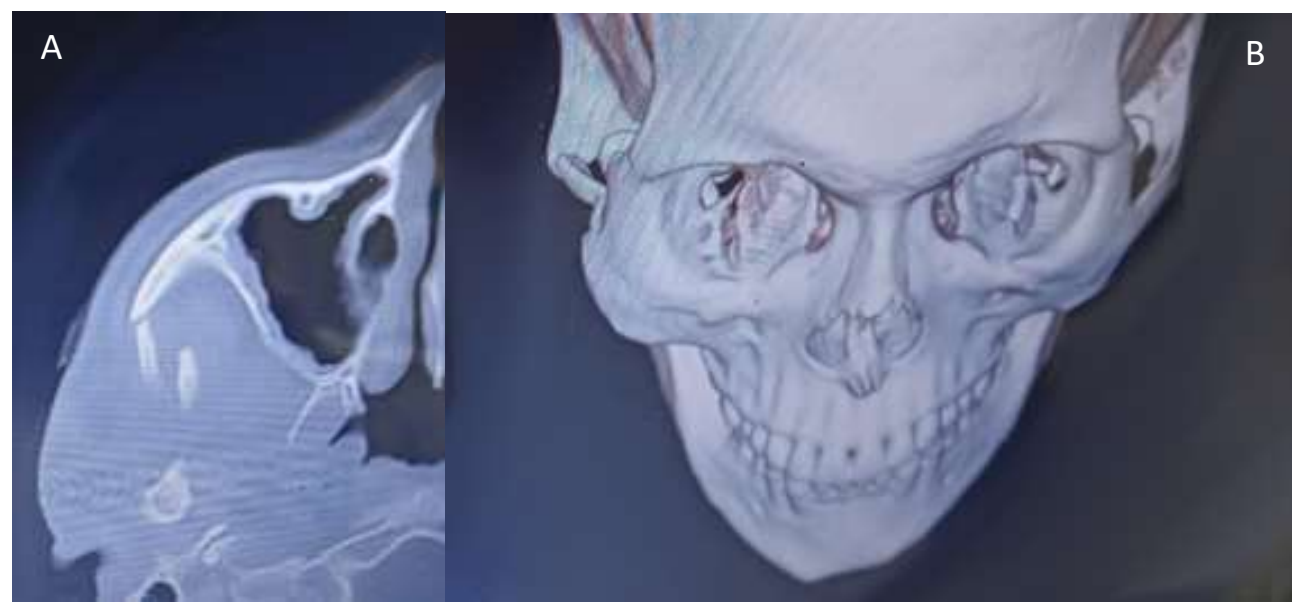

Source: Authors.

In Figure 2, on tomography the continuity solution was visible in the region of the right zygomatic arch (A), it is possible to see the displacement of the temporal portion of the zygomatic arch shifted to medial, very close to the coronoid process, which would justify the severe restriction of mouth opening. In $3 \mathrm{D}$ reconstruction, the degree of bone sinking in the region is evident $(\mathrm{B})$.

Ac cording to the clinical and tomographic parameters, it was decided to reduce the fracture under general anesthesia. During intubation, opening restriction proved to be a problem for conventional intubation, Bougie was used for possible tube guidance, but without success. The laryngeal mask was an alternative, however, due to the panoramic view of the covid-19, the option for videolaryngoscopy (Figure 3), coupled to the miller retractor, was introduced through the oropharynx, where the larynx compartments were fully visible.

Figure 3 - Use of videolaryngoscope during the intubation procedure.

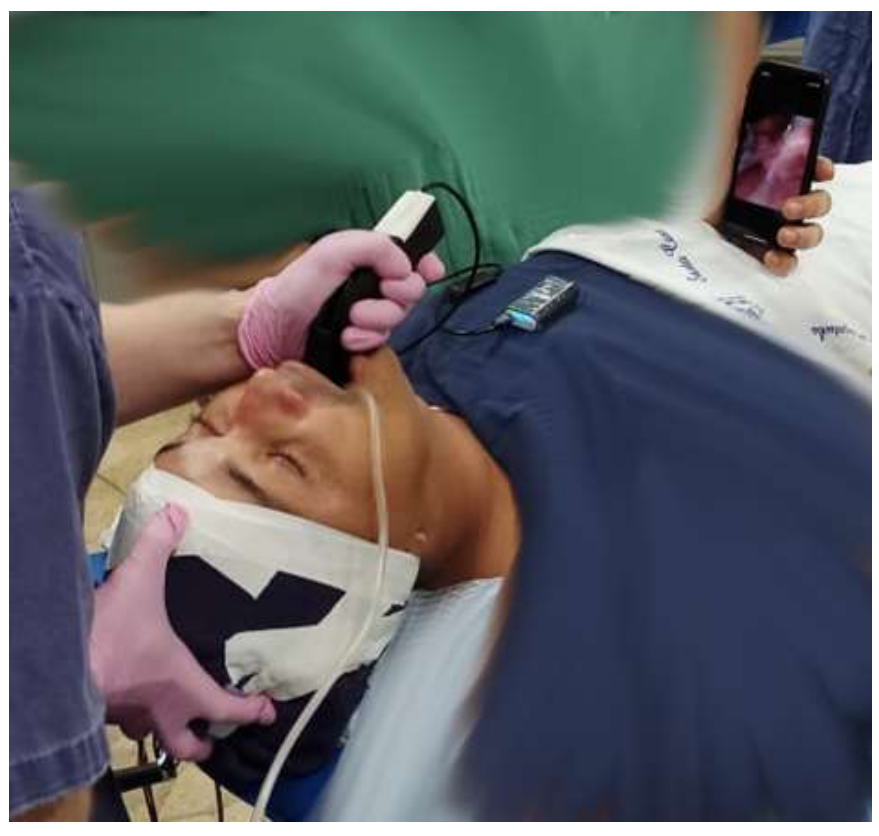

Source: Authors. 
In Figure 3, it is possible to see the anesthesiologist with the videolaryngoscope inserted in the patient's larynx region, where through the cell phone display it is possible to observe the structures that give access to the trachea, images reproduced by the camera remotely.

The corniculate cartilage was already swollen due to several attempts to introduce the tube. Guided by the video, the bougie was introduced and subsequently intubated with tube number $7.10 \mathrm{mg}$ of dexamethasone was used to control localized edema and the arch reduction surgery could be performed, returning the zygomatic arch projection and the natural excursion of the coronoid process, without further complications.

The zygomatic arch was repositioned and the patient's mouth opening reestablished. Postoperative computed tomography was requested, which proved the good fracture reduction, as can be seen in Figure 4.

Figure 4 - Postoperative computed tomography.

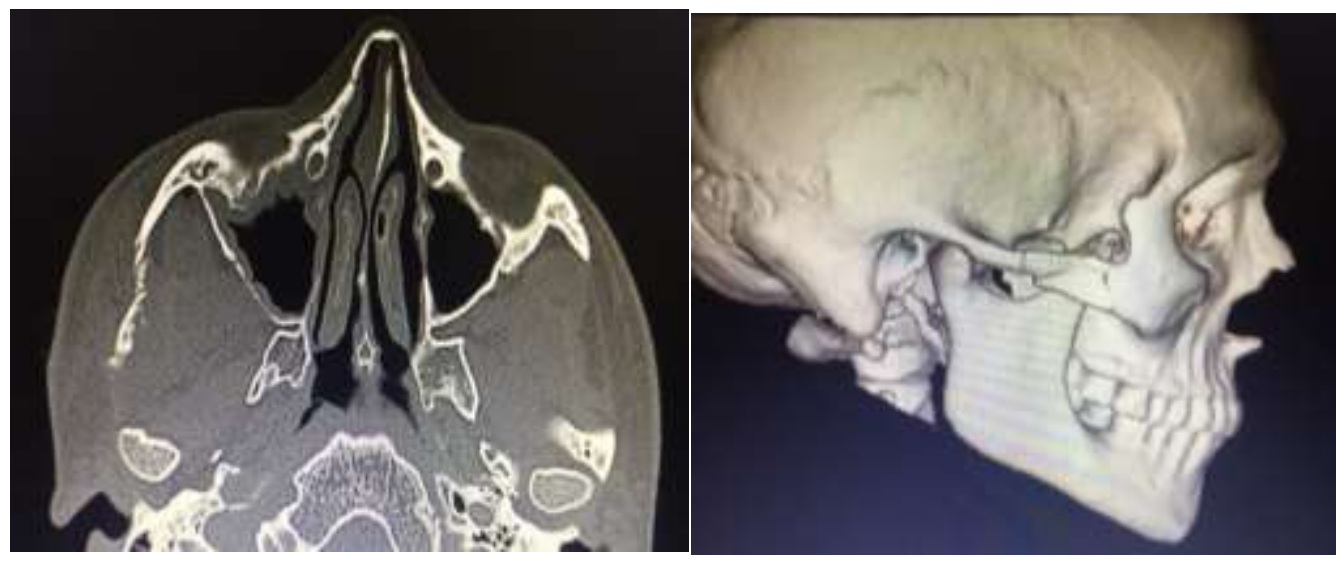

Source: Authors.

In Figure 4, it is possible to observe the reestablishment of the contour of the zygomatic arch, which previously prevented the physiological movement of the mandibular condyle.

\section{Discussion/ Review}

The zygomatic arch is a structural component of the zygomatic complex considered one of the most fragile structures of the facial skeleton and responsible for maintaining the anteroposterior projection of the zygoma. Due to their fragility and location, fractures of the zygomatic arch comprise almost $10 \%$ of the complex's fractures and can be caused by forces of lesser intensity. Clinically, fractures of the zygomatic arch lead to depression or bulging in the topography of the arch, facial asymmetry, pain and crackling on palpation, limitation of mouth opening by blocking the coronoid process of the mandible, in addition to the formation of edema (Chang et al., 2012, Trindade et al., 2012, Manganello-Souza et al., 2003, Pereira et al., 2014).

As a result of conditions such as this, in which the patient has particularities that can characterize difficult intubation, such as limited mouth opening, it is of fundamental importance that videolaryngoscopy is an alternative available to the anesthesiologist, since it can facilitate the intubation process in function of providing an indirect but more comprehensive view because they have a camera lens close to the tip of the blade closest to the larynx (Ciccozzi et al., 2013, Kilicaslan et al., 2014, Apfelbaum et al., 2013, Jungbauer et al., 2009, Berkow et al., 2018, Niforopoulou et al., 2010).

In comparison with direct laryngoscopy, videolaryngoscopy has constantly shown an increase in the success rate of the first pass, with improved laryngeal vision and glottic exposure, in addition to decreased pressure on the teeth and the 
strength of intubation (Kilicaslan et al., 2014, Aziz et al., 2012, Berkow et al., 2018, Niforopoulou et al., 2010). The Difficult Airway Society currently recommends that a videolaryngoscope be available whenever there is a need for intubation, although many anesthesiologists are not yet familiar with the equipment and it has a high cost (Berkow et al., 2018).

In a study conducted by Kilicaslan et al. (2014), data from 42 patients whose attempts at intubation with direct laryngoscopy using Macintosh had failed and in which the C-MAC videolaryngoscope was used as the primary rescue device were analyzed. According to the results obtained, videolaryngoscopy with C-MAC has been shown to increase the success rate in cases of unexpected difficult intubation and to improve visualization of the glottis, providing evidence of the clinical effectiveness of videolaryngoscopy in unexpected unsuccessful intubations.

In a prospective randomized controlled trial, Erdivanli et al. (2018) compared the efficiency of the King Vision videolaryngoscope and the Macintosh laryngoscope when used by experienced anesthesiologists in different intubation conditions of adult patients. Regarding successful intubation on the first attempt, laryngoscopes did not show statistically significant differences. However, in terms of time to better glottis visualization and intubation time, the King Vision videolaryngoscope proved to be inferior to the Macintosh laryngoscope.

Although the current evidence still has gaps for this technique to be considered as a standard of care, video laryngoscopes are being increasingly used and considered first-line intubation devices for difficult, rescue and routine intubations, achieving the same or higher success rate compared to direct laryngoscopy and the tendency is for an improvement in the characteristics of the devices until the ideal videolaryngoscope is found (Ciccozzi et al., 2013, Erdivanli et al., 2018, Kilicaslan et al., 2014, Nausheen et al., 2019, Berkow et al., 2018, Niforopoulou et al., 2010).

In summary, it is important to carry out further studies in search of the ideal video laryngoscopes and the main indications for their use, where they bring together the advantages offered by this equipment and are easily accepted by the professional, since its use and handling requires aptitude for such.

\section{Final Considerations}

A good planning of the intubation carried out by the anesthesiologist together with the CTBMF team, combined with the availability of new technologies that assist during orotracheal intubation such as videolaryngoscopy, both in public and private services, can be the differential between a successful and intubation an unsuccessful one since muscle relaxants alone are not enough to get around difficult situations. In addition, with good planning, time is saved, physical exhaustion on the part of professionals and a better postoperative result is obtained for the patient, as well as the safety in general of the procedure as a whole.

\section{Acknowledgments}

We would like to thank the São Paulo Research Foundation for the scholarship granted by FAPESP Process $\mathrm{N}^{\circ}$ 2019/12331-8.

\section{References}

Apfelbaum, J. L., Hagberg, C. A., Caplan, R. A., Blitt, C. D., Connis, R. T., \& Nickinovich, D. G. (2013). Diretrizes Práticas para o Tratamento da Via Aérea Difícil: Um relatório atualizado da Força-Tarefa da Sociedade Americana de Anestesiologistas sobre o Tratamento das Vias Aéreas Difíceis. Anesthesiology Trusted Evidence: Discovery to Practice, 118(2), 251-270.

Aziz, M. F., Dillman, D., Fu, R., \& Brambrink, A. M. (2012). Eficácia comparativa do videolaringoscópio C-MAC versus laringoscopia direta no cenário de via aérea difícil prevista. Anesthesiology Trusted Evidence: Discovery to Practice, 116(3), 629-636.

Berkow, L. C., Morey, T. E., \& Urdaneta, F. (2018). A tecnologia da videolaringoscopia, Anesthesia \& Analgesia, 126(5), 1527-1534. 
Chang, C., Ko, E. C., Kao, C., Chang, P., \& Yc Chen, M. (2012). Incidência e significado clínico de fratura do complexo zigomático-maxilar envolvendo a articulação temporomandibular com ênfase no trismo. Kaohsiung Journal of Medical Sciences, 28(6), 336-340.

Ciccozzi, A., Angeletti, C., Guetti, C., Papola, R., Angeletti, P. M., Paladini, A., Varrassi, G., \& Marinangeli, F. (2013). GlideScope e Frova Introducer for Difficult Airway Management. Case Reports in Anesthesiology, 2013(1), 1-7.

Cunha Andrade, R. G. A., Lima, B. L. S., Oliveira Lopes, D. K., Couceiro Filho, R. O., Cavalcanti Lima, L., \& Menezes Couceiro, T.C. (2018). Dificuldade na laringoscopia e na intubação orotraqueal: estudo observacional. Brazilian Journal of Anesthesiology, 68(2), $168-173$.

Delanora, L. A.; Baggio, A. M. P.; Farah, G. J.; Faverai, L. P. Relationship between chemical dependents, blood pressure values and Dentist Surgeon performance. Research, Society and Development, [S. l.], v. 9, n. 8, p. e847986203, 2020. DOI: 10.33448/rsd-v9i8.6203. Disponível em: https://rsdjournal.org/index.php/rsd/article/view/6203.

Detsky, M. E., Jivraj, N., Adhikari, N. K., Friedrich, J. O., Pinto, R., Simel, D. L., Wijeysundera, D. N., \& Scales, D. C. (2019). Will This Patient Be Difficult to Intubate? The Rational Clinical Examination Systematic Review, 321(5), 493-503.

Erdivanli, E., Sen, A., Batcik, S., Koyuncu, T., \& Kazdal, H. (2018). Comparison of King Vision video laryngoscope and Macintosh laryngoscope: a prospective randomized controlled clinical trial. Brazilian Journal of Anesthesiology, 68(5), 499-506.

Jungbauer, A., Schumann, M., Brunkhorst, V., Börgers, A., \& Groeben, H. (2009). Intubação traqueal difícil esperada: uma comparação prospectiva de laringoscopia direta e videolaringoscopia em 200 pacientes, BJA: British Journal of Anesthesia, 102(4), 546-550.

Kilicaslan, A., Topal, A., Tavlan, A., Erol, A., \& Otelcioglu, S. (2014). Eficácia do videolaringoscópio C-MAC no manejo de intubações malsucedidas inesperadas. Brazilian Journal of Anesthesiology, 64(1), 62-65.

Manganello-Souza, L. C, Silva, A. A. F., \& Pacheco, D. F. S. (2003). Fraturas Zigomáticas e Orbitozigomáticas. Rev Bras Cir Plást, 18(2), 24-30.

Nausheen, F., Niknafs, N. P., MacLean, D. J., Olvera, D. J., Wolf Jr, A. C., Pennington, T. W., \& Davis, D. P. (2019). Os critérios do HEAVEN predizem a visão laringoscópica e o sucesso da intubação para laringoscopia direta e videolaringoscópica: uma análise de coorte. Scand J Trauma Resusc Emerg Med 27, 50 .

Niforopoulou P., Pantazopoulos I., Demestiha T., \& Koudouna, E., (2010). Video-laryngoscopes in the adult airway management: a topical review of the literature. Acta Anaesthesiol Scand, 54(9), 1050-61.

Pereira, A.S., Shitsuka, D.M., Parreira, F.J., \& Shitsuka, R. (2018). Methodology of cientific research. Santa Maria: UAB / NTE / UFSM. Recuperado de: https://repositorio.ufsm.br/bitstream/handle/1/15824/Lic_Computacao_Metodologia-Pesquisa-Cientifica.pdf?sequence=1\&isAllowed=y

Pereira, C. C. S., Souza, A. P. de, Gaetti Jardim, E. C., Melo, R. L., Viegas, A. M., Cardoso, L. de C., \& Okamoto, R. (2014). Obstrução Mecânica da Mandíbula por Fratura Isolada do Arco Zigomático: Relato de Caso. ARCHIVES OF HEALTH INVESTIGATION, 3(1), 64-67.

Selvi, O., kahraman, S. T., Tulgar, S., Senturk, O., Serifsoy, T. E., Thomas, D., Cinar, A. S., \& Ozer, Z. (2020). Effectiveness of simplified predictive intubation difficulty score and thyromental height in head and neck surgeries: an observational study. Brazilian Journal Of Anesthesiology, 70(6), 595-604.

Trindade, P. A. K., Hochulli Vieira, E., Gabrielli, M. A. C., Gabrielli, M. F. R., \& Pereira-Filho, V. A. (2012). Treatment and Complications of Orbitozygomatic Fractures. Int J Odontostomat 6(3), 255-262.

Turcio, K. H. L., Pereira de Caxias, F., Micheline dos Santos, D., Junqueira Zuim, P. R., \& Gennari Filho, H. (2017). Diagnóstico diferencial de limitação de abertura bucal. Revista Odontológica de Araçatuba, 38(2), 15-21. 